\title{
Abelson tyrosine kinase links PDGFbeta receptor activation to cytoskeletal regulation of NMDA receptors in CAI hippocampal
} neurons

\author{
Michael A Beazely1, Manjula Weerapura ${ }^{1}$ and John F MacDonald*1,2,3
}

Address: ${ }^{1}$ Department of Physiology, University of Toronto, 1 King's College Circle, Toronto, ON M5S 1A8, Canada, ${ }^{2}$ Department of Pharmacology, University of Toronto, 1 King's College Circle, Toronto, ON M5S 1A8, Canada and ${ }^{3}$ The Robarts Research Institute, 100 Perth Drive, University of Western Ontario, London, ON N6A 5K8, Canada

Email: Michael A Beazely - mbeazely@uwaterloo.ca; Manjula Weerapura - mweerapura@neuromed.com; John F MacDonald* - jmacd53@uwo.ca

* Corresponding author

Published: 12 December 2008

Molecular Brain 2008, I:20 doi:10.1 I86/1756-6606-I-20
Received: 14 August 2008

Accepted: 12 December 2008

This article is available from: http://www.molecularbrain.com/content/I/I/20

(C) 2008 Beazely et al; licensee BioMed Central Ltd.

This is an Open Access article distributed under the terms of the Creative Commons Attribution License (http://creativecommons.org/licenses/by/2.0), which permits unrestricted use, distribution, and reproduction in any medium, provided the original work is properly cited.

\begin{abstract}
Background: We have previously demonstrated that PDGF receptor activation indirectly inhibits $\mathrm{N}$-methyl-D-aspartate (NMDA) currents by modifying the cytoskeleton. PDGF receptor ligand is also neuroprotective in hippocampal slices and cultured neurons. PDGF receptors are tyrosine kinases that control a variety of signal transduction pathways including those mediated by PLC $\gamma$. In fibroblasts Src and another non-receptor tyrosine kinase, Abelson kinase (Abl), control PDGF receptor regulation of cytoskeletal dynamics. The mechanism whereby PDGF receptor regulates cytoskeletal dynamics in central neurons remains poorly understood.

Results: Intracellular applications of active Abl, but not heat-inactivated Abl, decreased NMDAevoked currents in isolated hippocampal neurons. This mimics the effects of PDGF receptor activation in these neurons. The Abl kinase inhibitor, STI57I, blocked the inhibition of NMDA currents by Abl. We demonstrate that PDGF receptors can activate Abl kinase in hippocampal neurons via mechanisms similar to those observed previously in fibroblasts. Furthermore, PDGF $\beta$ receptor activation alters the subcellular localization of $\mathrm{Abl}$. Abl kinase is linked to actin cytoskeletal dynamics in many systems. We show that the inhibition of NMDA receptor currents by Abl kinase is blocked by the inclusion of the Rho kinase inhibitor, Y-27632, and that activation of Abl correlates with an increase in ROCK tyrosine phosphorylation.
\end{abstract}

Conclusion: This study demonstrates that PDGF $\beta$ receptors act via an interaction with Abl kinase and Rho kinase to regulated cytoskeletal regulation of NMDA receptor channels in CAI pyramidal neurons.

\section{Background}

Long-term potentiation (LTP) and long-term depression (LTD) are forms of plasticity which occur at the synapses between CA3 and CA1 pyramidal neurons of the hippocampus and they underlie some forms of spatial learning and memory $[1,2]$. Their induction is dependent upon the activation of $\mathrm{N}$-methyl-D-aspartate (NMDA) receptors $[3,4]$. These receptors make a relatively minor contribution to the basal excitatory synaptic potential but they are recruited during high frequency stimulation when the 
depolarizations summate and cause a relief of their block my $\mathrm{Mg}^{2+}$. The NMDA receptor currents must be further enhanced during the high frequency stimulation by the calcium-dependent activation of Pyk2 and Src kinases in order to induce LTP [5]. Src is brought into proximity of the NMDA receptors through its binding to ND2, a protein which serves as a structural and morphological scaffold for the regulation of NMDA receptors by Src [6]. A variety of $\mathrm{G} \alpha$ q-coupled receptors stimulate phospholipase C (PLC) $\beta$ and PKC and enhance NMDA receptors by targeting the Pyk2/Src regulation of NMDA receptors in CA1 neurons [7].

NMDA receptors bind directly to a variety of other scaffolding proteins including actin binding proteins [8]. Actin binding proteins link these receptors to the actin cytoskeleton and these protein-protein interactions are regulated by calmodulin binding and the influx of calcium via NMDA receptors such that the activity of these receptors is closely linked to actin cytoskeletal dynamics [8]. This actin anchoring may be permissive for the mechano-sensitivity of NMDA receptors [9] and is required for the inhibition of NMDA receptors by myosin light chain kinase and F-actin [10]. Therefore, actin cytoskeleton dynamics are pivotal to regulation of NMDA receptors.

LTD of the NMDA receptor-mediated component of the excitatory synaptic postsynaptic currents (epscs) is blocked by inhibition of serine-threonine phosphatases and can be prevented by using agents that stabilize the cytoskeleton in CA1 neurons [11]. We have previously shown that stimulation of the dopamine D2 receptor (a Gai-coupled receptor) results in transactivation of platelet derived growth factor $\beta$ (PDGF $\beta$ ) receptors $[12,13]$ and in turn PDGF $\beta$ receptor activation causes a long-lasting depression of NMDA receptor currents in CA1 neurons $[12,14,15]$ that resembles the LTD of NMDA receptor epscs. For example, inhibition of NMDA receptor currents by the PDGF $\beta$ receptor is prevented by the serine-threonine phosphatase inhibitor calyculin $\mathrm{A}$ and is also dependent on the stability of the actin cytoskeleton $[14,15]$. The mechanism(s) whereby PDGF $\beta$ receptor signaling modifies the actin cytoskeleton in CA1 neurons to regulate NMDA receptor currents is unknown, however the inhibition does require activation of PLC $\gamma$ and it is both calcium- and Src-dependent [14].

In a variety of cell types PDGF $\beta$ receptors form a signal complex with PLC $\gamma$, Src and a second tyrosine kinase, Abelson (Abl) kinase and downstream signaling is dependent upon interplay between of these enzymes [16]. Abl kinase is implicated in mechanisms of synaptic plasticity, plays a crucial role in growth cone motility, and is involved dendritic branching in developing neurons [1720]. In Abl and Abl-related gene (Arg) double-knock out mice, the extent of dendritic branching in substantially reduced [20] and treatment of developing cultured neurons with the Abl inhibitor, STI571, decreases the complexity of neuronal dendritic branching via an increase in RhoA activity [21] and possible activation of Rho-associated kinase (ROCK) [22-24]. Despite the identification of $\mathrm{Abl}$ as an important regulator of several neuronal processes, it remains unclear how $\mathrm{Abl}$ is activated in neurons. In several systems, Abl kinases are also required for Rhofamily GTPase coupling to the actin cytoskeleton and can reciprocally signal to ROCK [25]. Given the signaling connection between PDGF $\beta$ receptors and $\mathrm{Abl}$ as well as the evidence of $\mathrm{Abl}$ kinase regulation of neuronal signaling and development, we examined the possibility that in CA1 neurons Abl kinase is activated downstream of PDGF $\beta$ receptors and that $\mathrm{Abl}$ acting with ROCK is responsible for the alterations in actin cytoskeleton that underlie long-term depression of NMDA receptor activity.

\section{Results}

\section{Abl kinase inhibits NMDA-evoked currents}

To examine the effects of Abl on NMDA currents, we acutely dissociated CA1 neurons from 2-3 week old Wistar rats. Whole cell NMDA currents were evoked by applying $50 \mu \mathrm{M}$ NMDA and $0.5 \mu \mathrm{M}$ glycine for 2 seconds every minute. Intracellular application of $0.5 \mu \mathrm{g} / \mathrm{mL}$ active Abl kinase resulted in a time-dependent depression of NMDA currents (Figure 1A). After 25 minutes, NMDA currents were reduced by $53 \pm 5 \%$ (Figure $1 \mathrm{~A}, \mathrm{~B}$ ). In contrast, the inclusion of heat-inactivated Abl kinase in the patch pipette did not depress NMDA currents such that peak currents were maintained for the 25 minutes of recording $(104 \pm 8 \%$, Figure $1 \mathrm{~A}, \mathrm{C})$.

Chromosomal translocations involving Abl kinase result in a constitutively active kinase that causes chronic myeloid leukemia [26]. Recently, STI571 (imatinib mesylate, Gleevec $^{\mathrm{TM}}$ ) has been used to successfully treat patients with this form of leukemia. STI571 is a potent inhibitor of Abl kinase as well as PDGF $\beta$ receptors with an $\mathrm{IC}_{50}$ value for $\mathrm{Abl}$ in the low micromolar range $[27,28]$. Active Abl kinase was introduced into the cell via the patch pipette whereas STI571 was added to the ECF. STI571 $(2.5 \mu \mathrm{M})$ completely blocked the inhibition of NMDA currents by Abl kinase (Figure 1D). The inhibition of NMDA currents by Abl returned upon the washout of STI571 from the ECF (Figure 1E). These data show that STI571 inhibits the depression of NMDA currents induced by Abl and that this inhibition is reversible.

\section{PDGF receptors activate $A b l$ in the hippocampus}

Multiple signaling pathways including those initiated by PDGF $\beta$ receptors can activate the cytoplasmic pool of Abl kinase. To investigate the possibility that PDGF $\beta$ receptor activation could activate Abl kinase in hippocampal neu- 


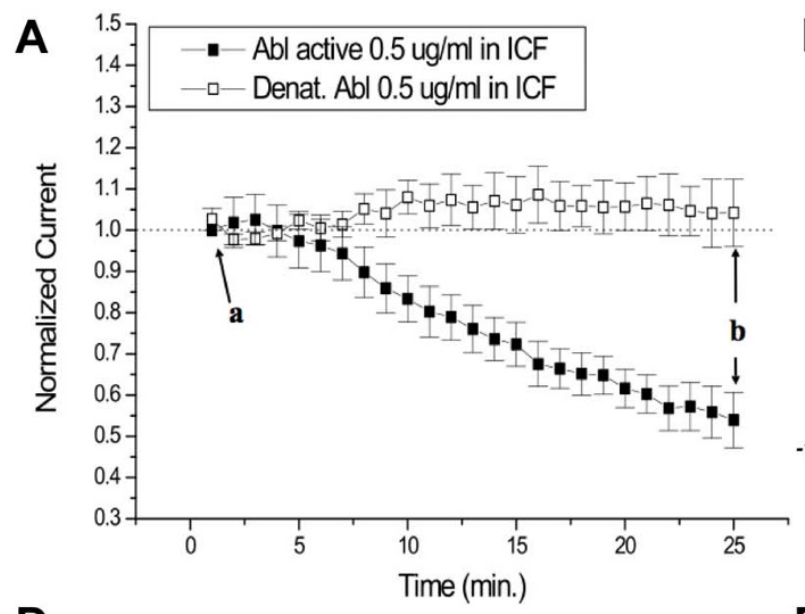

B

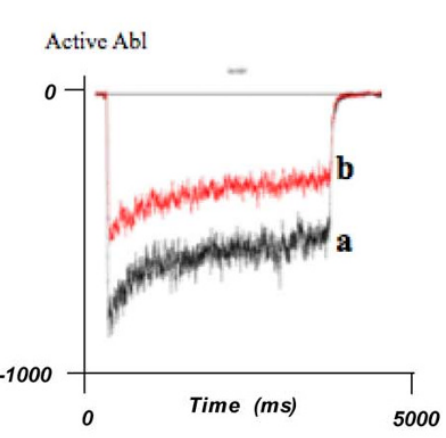

E
C Heat-inactivated Abl

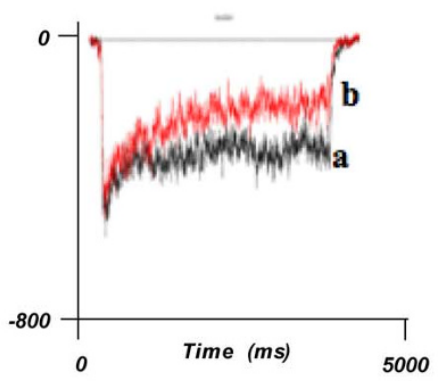

D

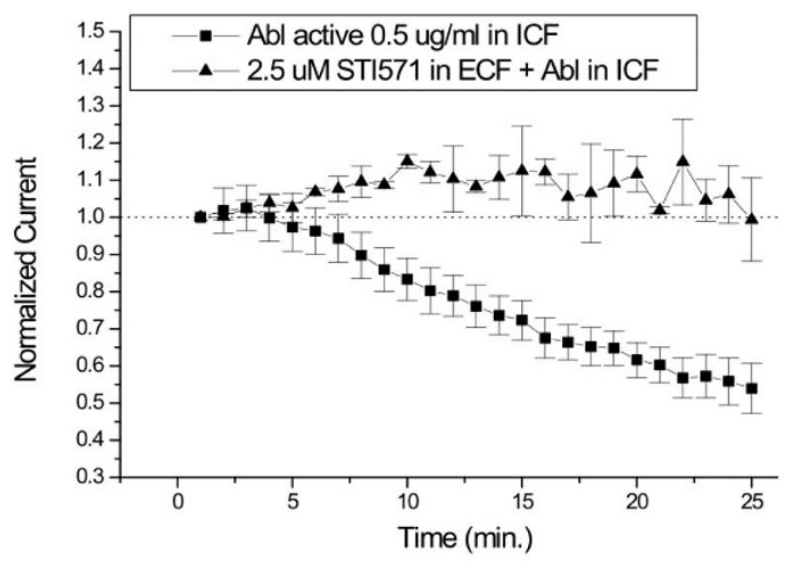

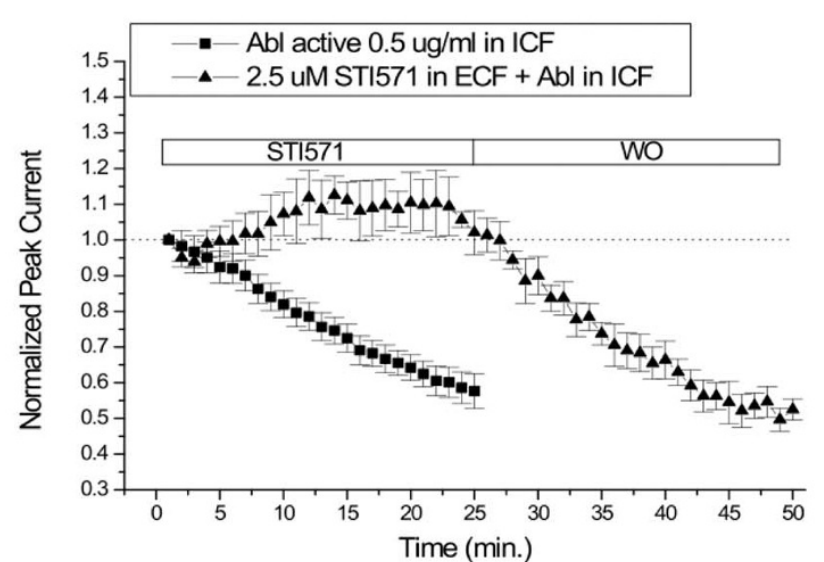

Figure I

Intracellular application of Abl decreases NMDA-evoked currents. A) Active (black square) or heat-inactivated (denat., white square) Abl kinase $(0.5 \mu \mathrm{g} / \mathrm{mL})$ was included in the intracellular solution. NMDA-evoked currents were recorded once every minute and peak currents were normalized to the average of the first five currents recorded. At 25 minutes (b) Abl significantly reduced NMDA-evoked currents ( $<<0.05$, Student's t-test, $n=6)$. B, C) Representative currents from currents recorded in the presence of active Abl kinase or heat-inactivated kinase at $t=3$ minutes (a) or $t=25$ minutes (b). D) NMDAevoked currents were recorded with active Abl kinase applied intracellularly in the ICF in the absence (black square) or presence (black triangle) of the Abl kinase inhibitor, STI57I, applied in the ECF bath $(n=6)$. E) NMDA-evoked currents were recorded with active Abl kinase applied intracellularly in the ICF in the absence (black square) or presence (black triangle) of the Abl kinase inhibitor, STI57I, applied in the ECF bath for 25 minutes (STI57I), followed by a 25 minute washout period (WO) during which control ECF solution was applied $(n=6)$.

rons, we incubated acutely dissected CA1 hippocampal slices with the PDGF $\beta$ receptor ligand, PDGF-BB. We then incubated CA1 hippocampal cell lysates with immobilized anti-PDGF $\beta$ receptor antibodies to examine whether PDGF $\beta$ receptors and Abl kinase physically associate in hippocampal neurons. Abl kinase was immunoprecipitated with PDGF $\beta$ receptors from hippocampal neurons and this association was significantly diminished upon PDGF-BB treatment of the hippocampal slices (Figure 2A, Abl immunoreactivity in PDGF receptor antibody pull- down was $0.65 \pm 0.12$ fold vs. control, $\mathrm{n}=7$, $\mathrm{p}<0.05$, unpaired Student's t-test). This observation supports the interpretation that $\mathrm{Abl}$ associates with PDGF $\beta$ receptors and is released upon activation of the receptor. To further examine the ability of PDGF $\beta$ receptors to activate Abl kinase in hippocampal neurons, we monitored the phosphorylation state of Abl kinase after incubation of hippocampal slices with PDGF-BB. Treatment with PDGF-BB for 10 minutes enhanced the tyrosine phosphorylation of $\mathrm{Abl}$ kinase (Figure 2B, $4.2 \pm 0.8$ fold vs. control, $\mathrm{n}=7, \mathrm{p}<0.05$ 
A

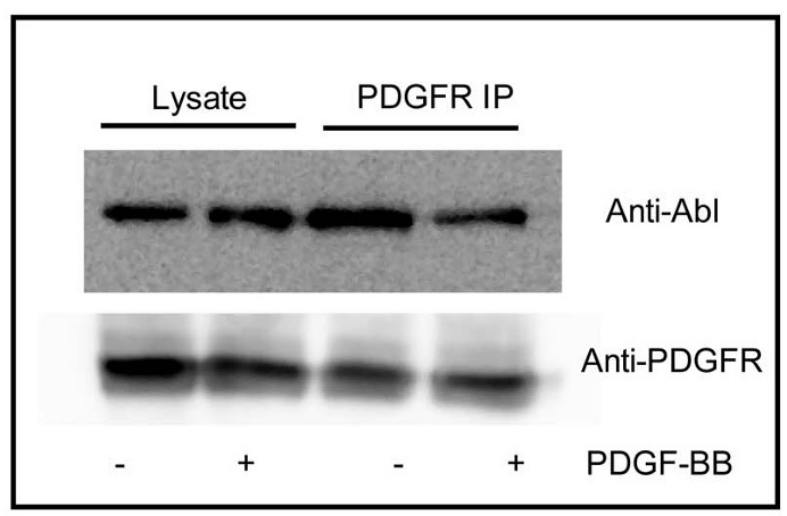

C

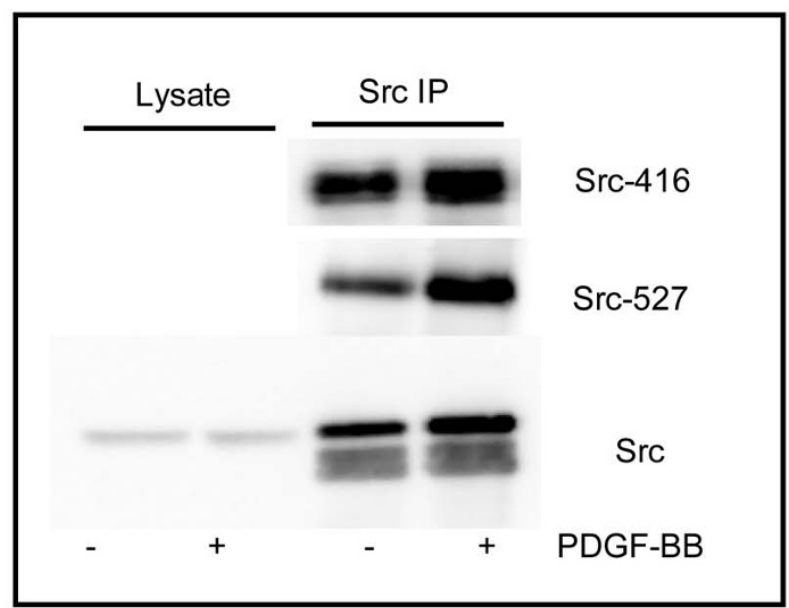

B

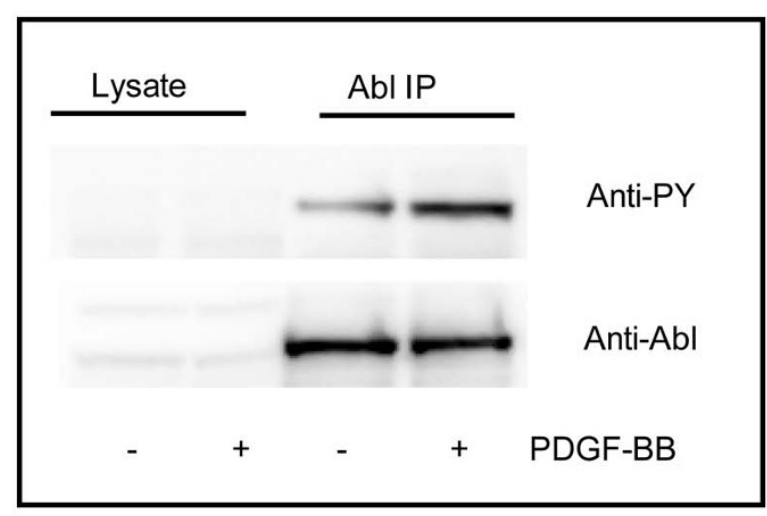

D

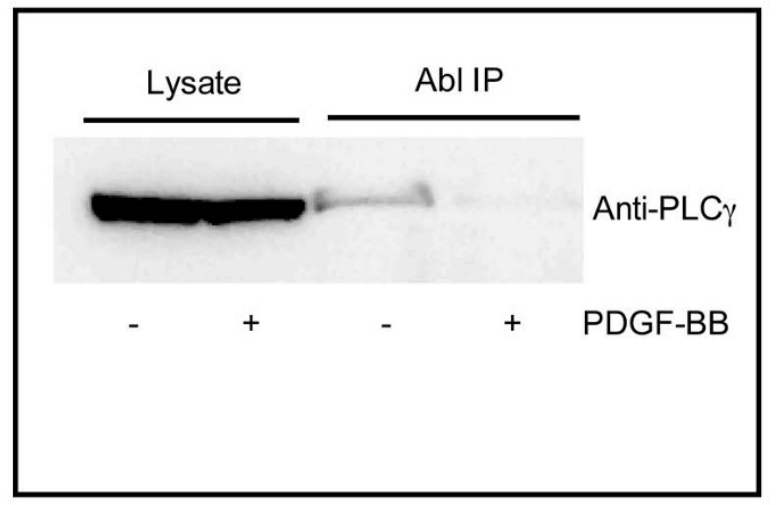

\section{Figure 2}

PDGF receptors activate Abl kinase in hippocampal neurons. Acutely dissected hippocampal CAI slices were incubated in the absence or presence of $10 \mathrm{ng} / \mathrm{mL}$ PDGF-BB for 10 minutes. A) Slices were homogenized and the lysate was incubated with anti-PDGF $\beta$ receptor antibodies precoupled to agarose beads. Total lysate and immunoprecipitated samples were immunoblotted with anti-Abl (top) or anti-PDGF $\beta$ receptor (bottom). Blots are representative of 7 experiments. B) Slices were homogenized and the lysates were immunoprecipitated with an anti-Abl antibody. Lysates and immunoprecipitates were resolved via SDS-Page electrophoresis and immunoblotted with anti-phospho-tyrosine (PY) or anti-Abl kinase antibodies. Blots are representative of 7 experiments. C) Anti-Src antibodies were used to immunoprecipitated Src after treatment of slices with $10 \mathrm{ng} / \mathrm{mL}$ PDGF-BB for 10 minutes. Immunoprecipitated samples were separated by SDS-electrophoresis and membranes were probed with anti-tyrosine 146 (Src-4I6), anti-tyrosine-527 (Src-527), or anti-Src (Src) antibodies. Blots are representative of 4-6 experiments. D) Lysates were immunoprecipitated with anti-Abl antibodies and membranes were probed with antiPLC $\gamma$ antibodies. Blot is representative of 5 experiments.

unpaired Student's t-test). These data show that treatment of CA1 hippocampal slices results in an increase in Abl tyrosine kinase phosphorylation and a change in the association of Abl kinase with the PDGF receptor.

We have previously demonstrated that both Src kinase and PLC $\gamma$ are required for the inhibition of NMDA-evoked currents by PDGF $\beta$ receptors [14,29]. PDGF $\beta$ receptor activation activates Abl in HEK293 cells in a Src- and
PLC $\gamma$-dependent manner [30,31]. PDGF-BB treatment of hippocampal slices enhanced the phosphorylation of both the tyrosine 416 (associated with increased Src activity) and tyrosine 527 (associated with decreased Src activity (Figure 2C) [32,33]. Consistent with previous studies examining the activation of Abl kinase, CA1 lysates immunoprecipitated with anti-Abl antibodies showed a

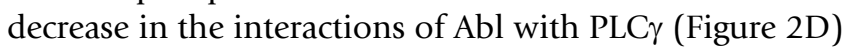
and Src (not shown). Taken together, these results suggest 
that Abl interacts with PDGF $\beta$ receptors, PLC $\gamma$, and Src in hippocampal neurons and activation of PDGF $\beta$ receptors decreases the association of Abl with these interacting partners as well as causing an increase in the tyrosine phosphorylation of Abl kinase.

\section{PDGF receptor activation decreases the cytoplasmic pool of Abl kinase}

Abl kinase is localized in both the synaptosomal and postsynaptic density fractions in adult rat brain homogenates [34] and Abl immunoreactivity is detected pre- and postsynaptically [18]. Upon stimulation of hippocampal slices with PDGF-BB, Abl kinase immunoreactivity decreased in both the S2 (cytosolic) and S3 (light membrane) fractions (Figure 3A, B). There was a trend towards an increase in immunoreactivity for $\mathrm{Abl}$ kinase in the triton-insoluble fraction (Figure 3A, B), suggesting that Abl kinase is moving from the cytosolic and light membrane fraction to the triton-insoluble fraction. Conversely, it is possible that Abl is being rapidly degraded in the S2 and S3 fractions. The NR1 subunit of the NMDA receptor was not significantly altered with respect to subcellular localization (Table 1).

\section{Abl inhibition of NMDA currents is blocked by the ROCK inhibitor Y-27632}

Both PDGF $\beta$ receptors and Abl kinase are involved in cytoskeletal dynamics in multiple systems [19,35,36]. Incubation of acutely dissociated hippocampal neurons with the Rho kinase (ROCK) inhibitor, Y-27632 ( IC $_{50}$ $0.3 \mu \mathrm{M}$ ) [37], attenuated the ability of intracellularlyapplied Abl kinase to inhibit NMDA currents (Figure 4A, B). PDGF-BB also enhanced the tyrosine phosphorylation of ROCK by $1.87+/-0.25$ (Figure 4C, p < 0.05, Student's unpaired t-test). Furthermore, ROCK underwent a similar change in subcellular localization as Abl kinase (Table 1). Abelson kinase is also associated with actin cytoskeletal dynamics via its association with WAVE1. Interestingly, Abl associates with WAVE1 in hippocampal neurons and treatment of hippocampal slices with PDGF-BB decreased the association of Abl with WAVE1 (Figure 4D) [38]. The ability of the ROCK inhibitor to block the Abl inhibition of NMDA currents implies that the inhibition of NMDA currents may be dependent on changes Abl-mediated alterations in the actin cytoskeleton.

\section{Discussion}

In the central nervous system, Abl kinase is involved with several crucial physiological processes. However the majority of studies have used transgenic deletions of Abl and/or Arg or small molecule inhibitors of the kinases $[20,21]$. Mechanisms of Abl regulation by cell surface receptors and intracellular signaling pathways in neurons remain unclear, and the role of Abl in post-synaptic neuronal signaling, specifically in NMDA receptor regulation, is unknown. We demonstrate that active Abl kinase inhibits NMDA currents in isolated hippocampal neurons. The inhibition of NMDA currents by Abl is completely and reversibly blocked by STI571, an Abl kinase (and PDGF $\beta$ receptor kinase) inhibitor. Although $\mathrm{Abl}$ and PDGF $\beta$ receptors may be inhibited by STI571, we have not previously observed a significant basal activity level of PDGF receptors in hippocampal neurons in previously published reports $[12,13]$ and unpublished observations.

Several lines of evidence link cell surface receptors to the activation of Abl kinase. The most detailed studies on the regulation of $\mathrm{Abl}$ involve the activation of $\mathrm{Abl}$ by PDGF $\beta$ receptors in fibroblasts $[30,31]$. In hippocampal neurons, Abl appears to be regulated by similar mechanisms. Abl associates with PDGF $\beta$ receptors, PLC $\gamma$, and Src in CA1 hippocampal neurons. Upon treatment of acutely isolated hippocampal slices with PDGF-BB, the association of Abl with each of these proteins is decreased and this coincides with an increase in tyrosine phosphorylation of $\mathrm{Abl}$ kinase.

Interestingly, PDGF-BB treatment increased the phosphorylation of Src at both tyrosine 416 (tyrosine phosphorylation here potentiates Src activity) and 527 (tyrosine phosphorylation inhibits Src activity) [39]. Activation of Src kinase via the phosphorylation of tyrosine 416 is associated with a potentiation of NMDA receptor currents and an increase in long-term potentiation [40-42]. However, we have previously demonstrated that application of PDGF-BB inhibits NMDA currents and that this inhibition is Src-dependent [14]. The identification of Abl as a downstream target in hippocampal neurons coupled with the requirement of Src to fully activate Abl after PDGF receptor activation may help reconcile the apparent contradiction in the requirement of Src for an inhibition of NMDA receptor currents by PDGF receptor activation and the direct potentiation of NMDA receptors by Src [14]. Recent work by Veracini et al. have identified least two distinct subcellular pools of Src mediating distinct signaling pathways in NIH $3 \mathrm{~T} 3$ cells $[43,44]$. The increases in tyrosine phosphorylation at both the inhibitory and activation tyrosine residues of Src in the hippocampus suggest the intriguing possibility that two or more pools of Src may be present in neurons as well. One pool interacting with the PDGF $\beta$ receptor and leading to a PLC $\gamma / \mathrm{Abl} / \mathrm{Src}$ complex that signals to the cytoskeleton via ROCK (with a resulting inhibition of NMDA receptors) and the other pool interacting directly with ND2 and the NMDA receptor complex to enhance NMDA receptor activity during LTP.

In cortical neurons, $\mathrm{Abl}$ and Arg are required for normal dendritic branching and are activated downstream of integrin receptors $[17,20]$. The regulation of dentritic spines and synapses are also important for synaptic plas- 
A

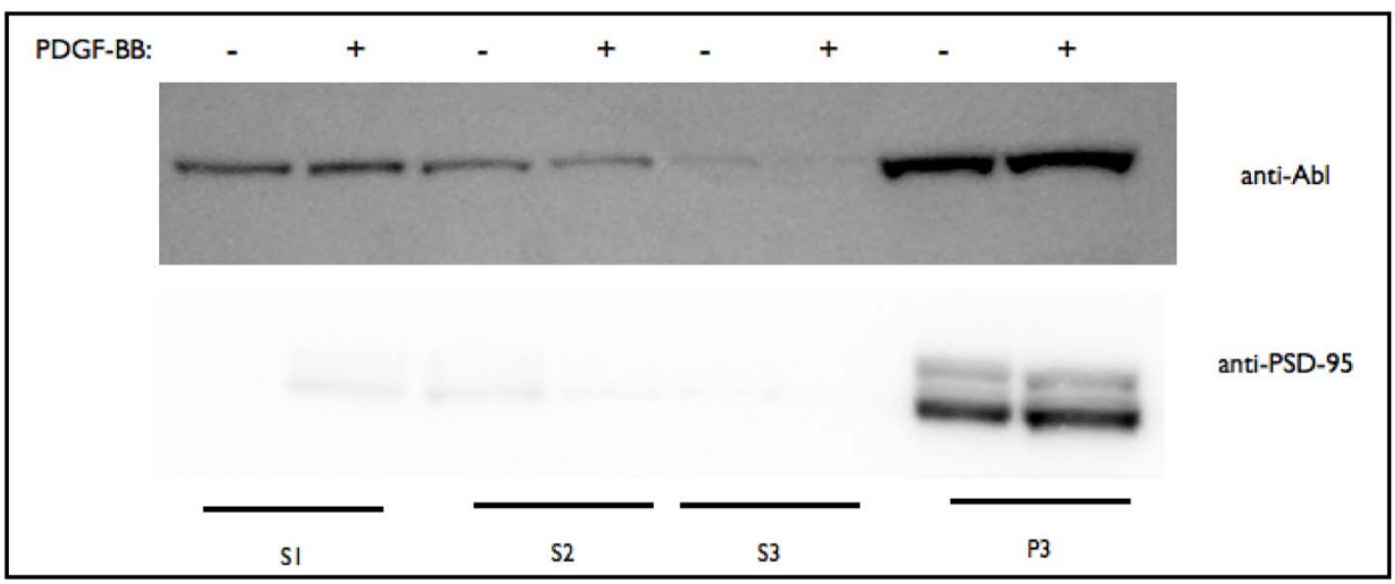

B

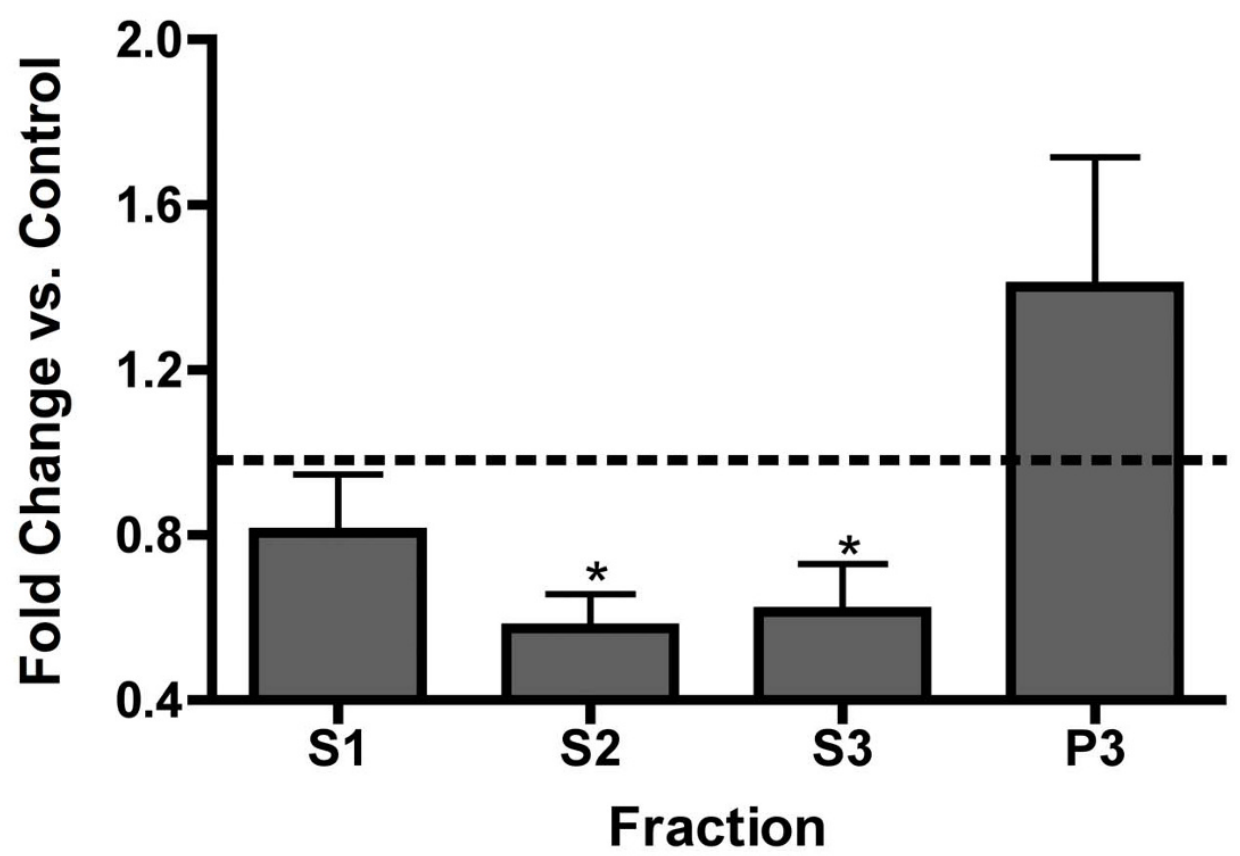

\section{Figure 3}

Abl kinase immunoreactivity is decreased in the S2 and S3 fractions after PDGF $\beta$ receptor activation. A) Hippocampal slices were treated for 10 minutes with $10 \mathrm{ng} / \mathrm{mL}$ PDGF-BB, were homogenized, and S2, S3, and P3 fractions were prepared as described in the methods section. Equal amounts of total protein from each fraction were resolved on SDS gels, transferred to nitrocellulose membranes, and immunoblotted with anti-Abl or anti-PSD-95 antibodies $(n=6)$. B) PDGF-BB treated fractions were normalized to control for each fractionation sample. Data represent the mean $+/$ - standard error for 6 independent experiments. PDGF-BB treatment significantly decreased Abl kinase immunoreactivity in the S2 and S3 fractions, * $P<0.05$, Student's unpaired t-test. 
Table I: The effect of PDGF-BB on the subcellular fractionation of PDGF $\beta$ receptors, ROCK, and NRI

\begin{tabular}{llll}
\hline Protein & \multicolumn{3}{l}{ Change in localization after PDGF-BB treatment } \\
\hline & S2 & S3 & P3 \\
\hline PDFG $\beta$ receptor & $n / a$ & $63 \pm 15 \%^{a}$ & $136 \pm 31 \%$ \\
\hline ROCK & $60 \pm 12 \%^{a}$ & $66 \pm 30 \%$ & $125 \pm 30 \%$ \\
\hline NRI & $n / a$ & $81 \pm 36 \%$ & $130 \pm 30 \%$
\end{tabular}

Hippocampal slices were treated for 10 minutes with $10 \mathrm{ng} / \mathrm{mL}$ PDGF-BB, were homogenized, and S2, S3, and P3 fractions were prepared as described in the methods section. Equal amounts of total protein from each fraction were resolved on SDS gels, transferred to nitrocellulose membranes, and immunoblotted with anti- PDFG $\beta$ receptor $(n=4)$, anti-ROCK $(n=3)$, or anti-NRI $(n=3)$ antibodies. Data represent the mean $+/$ - standard error, $a p<0.05$, Student's unpaired t-test.

ticity in mature neurons, and depends heavily on actin cytoskeleton dynamics $[45,46]$. In contrast to previous reports suggesting ROCK activity is inversely proportional to Abl activity $[23,47,48]$, treatment of hippocampal slices with PDGF-BB increased ROCK tyrosine phosphorylation. Furthermore, the ROCK inhibitor attenuated Ablinduced decreases in NMDA-evoked currents. These observations show that ROCK is required for Abl-mediated changes in the actin cytoskeleton that leads to inhibition of NMDA currents and that Abl-mediated inhibition of NMDA receptor currents requires RhoGTPase and ROCK signaling (Figure 5). Therefore, in addition to being crucial for neuronal development, Abl kinase regulates NMDA function in mature neurons and links PDGF $\beta$ receptor signaling to the actin cytoskeleton. Our results place Abl at an important intersection between alterations in the neuronal cytoskeleton and regulation of NMDA receptors.

\section{Conclusion}

PDGF-BB treatment decreased the association of Abl with PDGF $\beta$ receptors. Furthermore, PDGF-BB treatment reduced the association of Abl with PLC $\gamma$ and Src, suggesting that $\mathrm{Abl}$ is activated in hippocampal neurons in a manner similar as previously reported in non-neuronal cells. PDGF-BB treatment of hippocampal slices also induced a translocation of Abl from the cytosolic and membrane fraction to the triton-insoluble fraction. Previous studies have suggested that PDGF $\beta$ receptor activation ultimately alters NMDA receptor signaling by inducing changes in cytoskeletal dynamics and Abl kinase is linked in several systems to actin dynamics. Similar to extracellular treatment of neurons with PDGF-BB, the inclusion of Abelson kinase in the patch pipette robustly inhibited NMDA-evoked currents in isolated CA1 neurons and this inhibition was blocked by treatment of neurons with the Abl inhibitor STI571 and the ROCK inhibitor, Y-27632. These results suggest that PDGF $\beta$ receptors activate Abl kinase in hippocampal neurons and that Abl links PDGF $\beta$ receptor signaling to changes in the neuronal cytoskeleton that ultimately lead to changes in NMDA receptor signaling.

\section{Methods \\ Reagents and antibodies}

Active Abl kinase (mouse) was purchased from Upstate Biotechnology/Millipore (Belerica, MA). Each lot of active Abl kinase was tested for phosphorylation of a peptide substrate in an in vitro kinase assay (by the manufacturer). Briefly, each lot of Abl kinase had a specific activity ( 1750 units/mg) where 1 unit is defined as incorporating $1 \mathrm{nmol}$ phosphate into $50 \mu \mathrm{M}$ Abltide (EAIYAAPFAKKK) per minute at $30^{\circ} \mathrm{C}$ in the presence of $100 \mu \mathrm{M}$ ATP. PDGFBB was purchased from R\&D Systems (Minneapolis, MN, USA). Y-27632 was purchased from Calbiochem (San Diego, CA). NMDA, glycine, and all other chemical reagents were purchased from Sigma (St. Louis, MO, USA). Antibodies used include those raised against PDGF $\beta$ receptor (Epitomics, California, USA), Abelson kinase (Sigma), Src (Cell Signaling, Danvers, MDA) and phospho-Y416 and Y527 Src (Biosource, Carlsbad, CA), and phospho-tyrosine antibody (Santa Cruz, La Jolla, CA), and PLC $\gamma$, ROCK, and WAV1 (Cell signaling). For the immunoprecipitation of PDGF $\beta$ receptors, an agaroseconjugated anti-PDGF $\beta$ R antibody from Santa Cruz was employed.

\section{Cell isolation and whole-cell recording}

CA1 neurons were isolated from hippocampal slices of postnatal day 14-21 Wistar rats as previously described [49]. The extracellular solution was composed of $140 \mathrm{mM}$ $\mathrm{NaCl}, 1.3 \mathrm{mM} \mathrm{CaCl} 2,25 \mathrm{mM} \mathrm{N}$-2-Hydroxyethylpiperazine-N'-thanesulfonic acid (HEPES), $33 \mathrm{mM}$ glucose, 5.4 $\mathrm{mM} \mathrm{KCl}$, and $0.5 \mu \mathrm{M}$ tetrodotoxin, and $0.5 \mu \mathrm{M}$ glycine, with $\mathrm{pH}$ of 7.3-7.4 and osmolarity ranging from 320-330 mOsm. Recordings were done at room temperature. The membrane potential was held at $-60 \mathrm{mV}$ throughout the recordings and with a voltage step of $10 \mathrm{mV}$ was applied prior to NMDA application to monitor series resistance. Recordings were rejected if a series resistance change greater than $10 \%$ was observed. The intracellular solution consisted of $11 \mathrm{mM}$ Ethyleneglycol-bis-( $\alpha$-amino-ethyl ether) $\mathrm{N}, \mathrm{N}$-tetra-acetic acid (EGTA) as intracellular calcium chelating buffer, $10 \mathrm{mM}$ HEPES, $2 \mathrm{mM} \mathrm{MgCl} 2,2$ mM Tetraethyl ammonium chloride (TEA-Cl) to block $\mathrm{K}+$ channel, $1 \mathrm{mM} \mathrm{CaCl} 2,140 \mathrm{mM} \mathrm{CsF}$, and $4 \mathrm{mM}$ K2ATP. NMDA currents were evoked by rapid application of NMDA solution delivered from a multi-barreled fast perfusion system for 2 seconds in every minute. The solution was delivered at a rate of approximately $1 \mathrm{ml}$ per minute. 
A

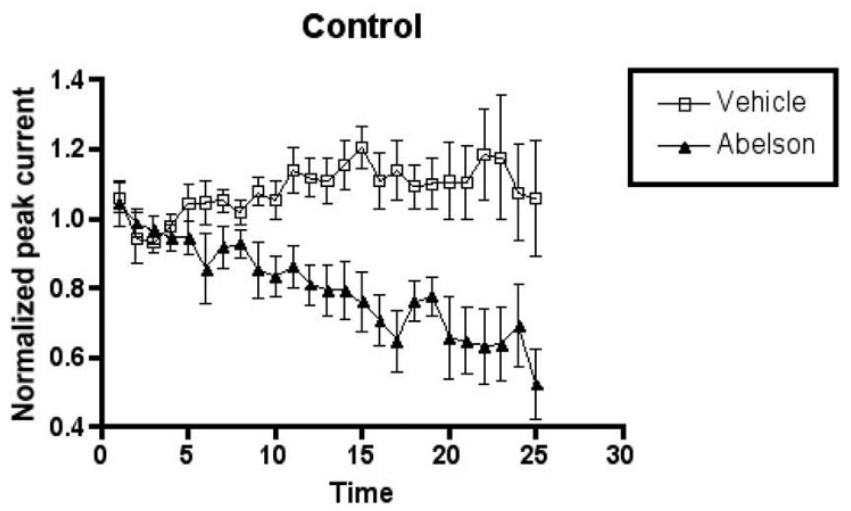

B

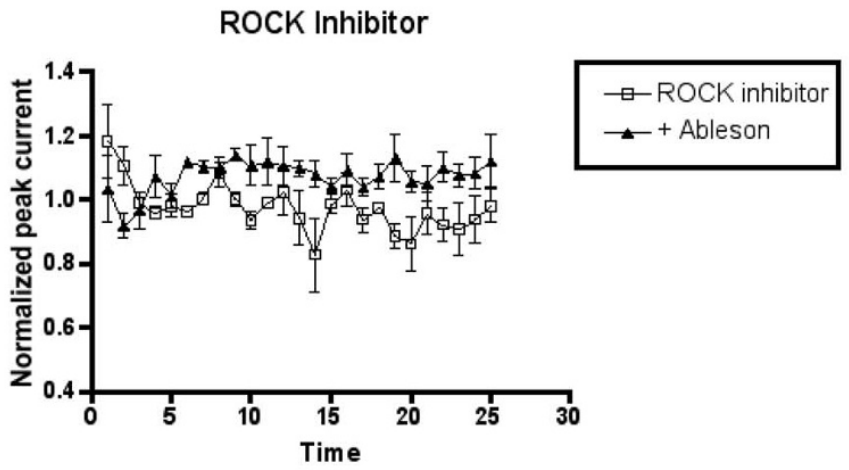

C

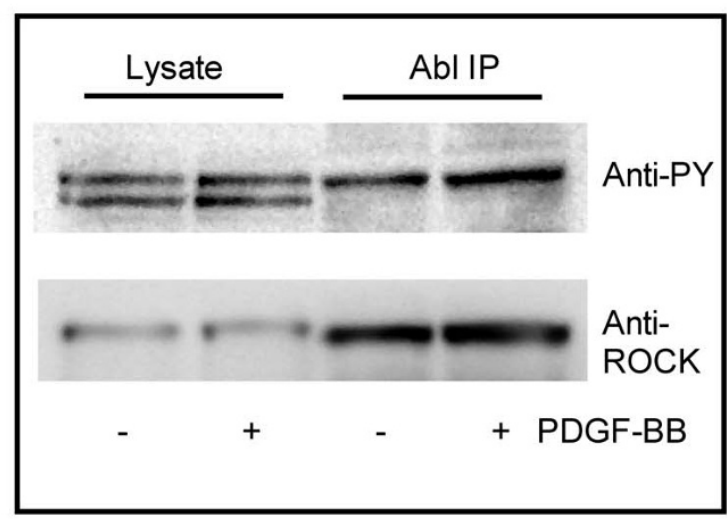

D

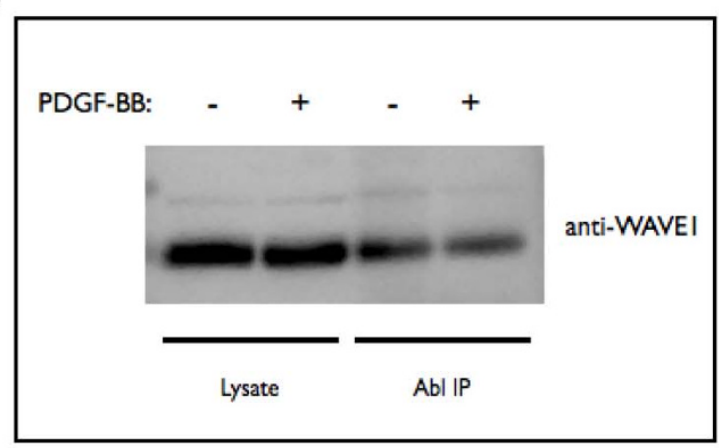

\section{Figure 4}

The ROCK inhibitor, Y-27632, attenuates Abl kinase-induced inhibition of NMDA evoked currents. A) Abl kinase (black triangle) or control (white square) was included in the intracellular solution. NMDA-evoked currents were recorded once every minute and peak currents were normalized to the average of the first five currents recorded $(n=7)$.). At 25 minutes Abl significantly reduced NMDA-evoked currents $(p<0.05$, Student's t-test, $n=5), B$ ) NMDA-evoked peak currents were recorded every minute in the presence of I $\mu \mathrm{M} Y-27632$ with control (ROCK inhibitor, white square) or Abl kinase (+Abelson, black triangle) included in the intracellular solution. Peak currents were normalized to the average of the first five currents recorded $(n=5)$. C) Slices were homogenized and the lysates were immunoprecipitated with an anti-ROCK antibody. Lysates and immunoprecipitates were resolved via SDS-Page electrophoresis and immunoblotted with anti-phosphotyrosine (PY) or anti-ROCK antibodies. Blots are representative of 4 experiments. D) Slices were homogenized and the lysates were immunoprecipitated with an anti-Abl antibody. Lysates and immunoprecipitates were resolved via SDS-Page electrophoresis and immunoblotted with anti-WAVEI antibody. Blot is representative of 4 experiments.

Abl or heat-inactivated $\mathrm{Abl}(0.5 \mu \mathrm{g} / \mathrm{mL})$ was added to the ICF.

\section{Immunoprecipitation and western blotting}

The CA1 region of the hippocampus was microdissected from day 14-22 Wistar rat pups. CA1 slices (5-10 per condition) were incubated for 10 minutes with vehicle or PDGF-BB. Slices were washed in ice-cold ECF and homogenized in solubilization buffer $(20 \mathrm{mM}$ Tris, $\mathrm{pH}=7.5,150$ $\mathrm{mM} \mathrm{NaCl}, 1 \mathrm{mM}$ EDTA, $1 \mathrm{mM}$ EGTA, $30 \mathrm{mM} \mathrm{Na}$ pyro- phosphate, $1 \mathrm{mM}$ ßglycerophosphate, $1 \%$ Triton (1\% NP40 was substituted for immunoprecipitation), $1 \mathrm{mM}$ Na3VO4, and MINI cocktail (Roche, Mannheim, Germany). Samples were centrifuged at $14,000 \times \mathrm{g}$ for 20 minutes and lysates were used for protein determination. Total protein concentration was determined by BCA Protein Assay (Pierce, Rockford, Il, USA). For Western blot, equal amounts of protein were loaded for each sample. For immunoprecipitations, lysate protein concentrations were normalized and lysates were incubated with primary 


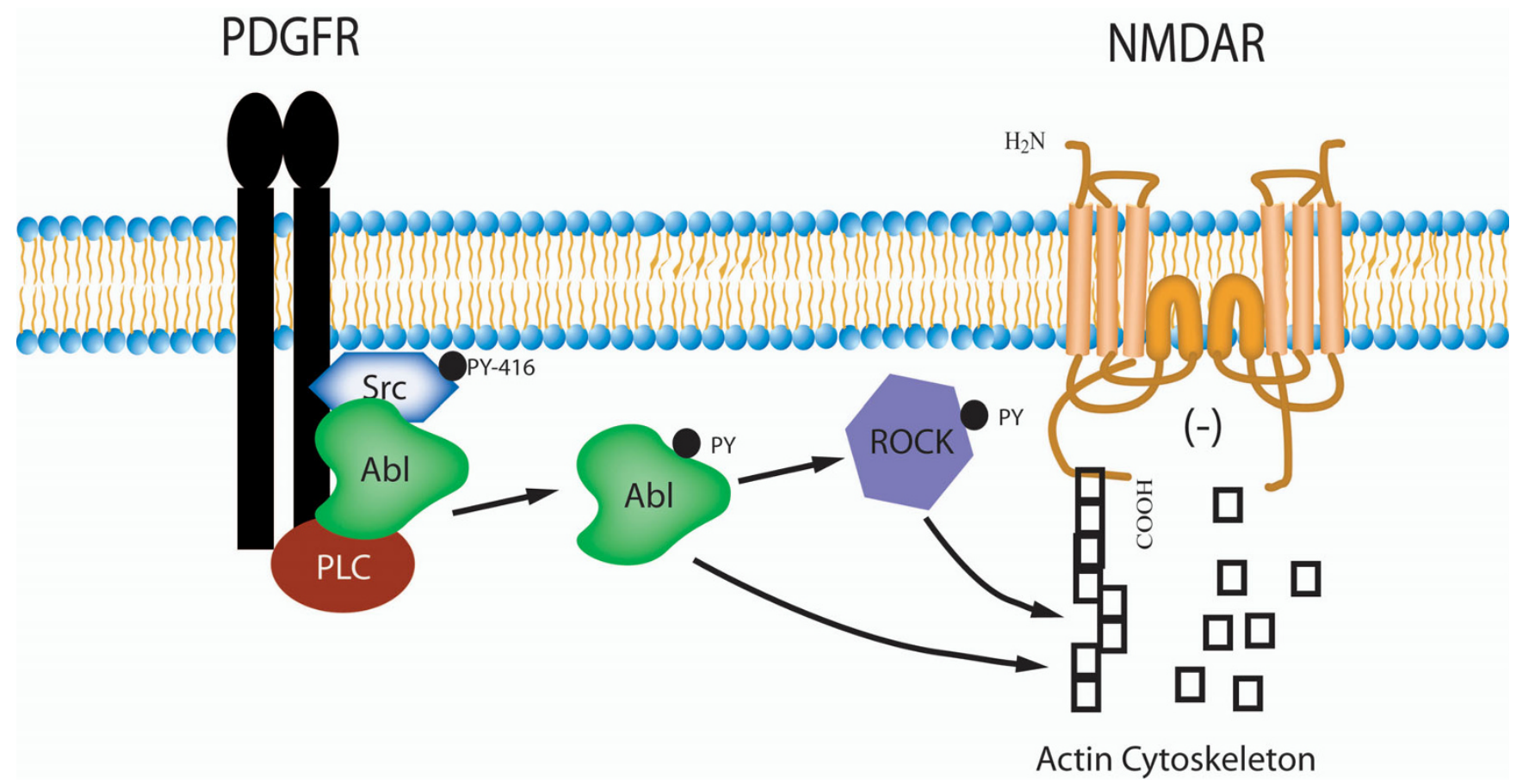

\section{Figure 5}

Abelson kinase associates with PDGF $\beta$ receptors and inhibits NMDA receptor currents in a ROCK-dependent manner. Abelson kinase (Abl) physically associates with PDGF $\beta$ receptors, PLC $\gamma$, and Src in hippocampal neurons. Upon activation of PDGF $\beta$ receptors, Abelson kinase is tyrosine-phosphorylated and dissociates from the receptor. Introduction of Abelson kinase into isolated hippocampal neurons robustly inhibits NMDA receptor currents in a ROCK-dependent manner, possibly through changes in the actin cytoskeleton.

antibody and protein A/G beads (Sigma) overnight at $4{ }^{\circ} \mathrm{C}$. Beads were washed three times and boiled in SDS loading buffer for 5 minutes before separation by SDS page electrophoresis. Proteins were transferred to nitrocellulose membranes, blocked with 5\% non-fat dry milk in Tris-buffered saline for $1 \mathrm{hr}$ at room temperature or overnight at $4^{\circ} \mathrm{C}$, and incubated in primary antibodies for $1 \mathrm{hr}$ or overnight at $4^{\circ} \mathrm{C}$. Membranes were washed three times in Tris-buffered saline with $0.1 \%$ Tween-20, incubated with HRP-conjugated secondary antibodies for $1 \mathrm{hr}$, washed again, and bound antibodies were visualized by the enhanced chemiluminescence method. Densitometric analysis of Western blots was performed using the Kodak Image Station 2000R software.

\section{Subcellular fractionation}

Hippocampal tissue was incubated with vehicle or PDGF$\mathrm{BB}$ and the tissue was dounce homogenized in fractionation buffer 1 to yield the S1 fraction (buffer 1: $0.32 \mathrm{M}$ sucrose, $4 \mathrm{mM}$ HEPES, pH 7.3, MINI protease inhibitor cocktail 1:10, and $1 \mathrm{mM} \mathrm{Na3VO} 4)$. The homogenized tissue was centrifuged at $1000 \times \mathrm{g}$ for 10 minutes at 4 degrees. The supernatant was retained and centrifuged at $14,000 \times \mathrm{g}$ for 20 minutes. The supernatant (S2) was retained and the insoluble material was resuspended in fractionation buffer 2 (buffer $1+1 \%$ triton). The resus- pended mixture was centrifuged at $100,000 \times \mathrm{g}$ for 60 minutes and the supernatant ( $\mathrm{S} 3$, triton-soluble membrane fraction) was retained. The pellet (P3) was resuspended and dissolved in fractionation buffer 3 (buffer $1+$ $0.5 \%$ SDS + 1\% deoxycholate). Protein concentration was determined by BCA protein assay and lysates were subjected to Western blotting as described above.

\section{Statistical analysis}

Statistical analysis of the data was completed using Prism ${ }^{\circledast}$ GraphPad program. Graphs and sample tracings were made from Origin ${ }^{\circledR}$ program. All data was reported as mean \pm SEM. Significance level was set at $\alpha=0.05$. Data was analyzed by Student's t-test or unpaired Student's ttest where appropriate.

\section{Animals}

All animal experiments were performed in agreement with the guidelines of the policies on the Use of Animal at the University of Toronto.

\section{Abbreviations}

NMDA: N-methyl-D-aspartate; PLC: phospholipase C; PDGF: platelet-derived growth factor; ROCK: Rho-associated kinase 


\section{Competing interests}

The authors declare that they have no competing interests.

\section{Authors' contributions}

$\mathrm{MAB}$ carried out the biochemical experimentation, contributed to electrophysiogical recording, and drafted the manuscript. MW carried out the electrophysiological recording. JFM participated in the design and coordination of the study and helped to draft the study

\section{Acknowledgements}

This work was supported by a grant to JFM from the Canadian Institutes of Health Research (155/4) and a postdoctoral award to MAB. MW received support from the Canadian Heart and Stroke Foundation.

\section{References}

I. Malenka RC, Bear MF: LTP and LTD: an embarrassment of riches. Neuron 2004, 44:5-2I.

2. Whitlock JR, Heynen AJ, Shuler MG, Bear MF: Learning induces long-term potentiation in the hippocampus. Science 2006, 3 13:1093-1097.

3. Collingridge GL: The Sharpey-Schafer Prize Lecture. The mechanism of induction of NMDA receptor-dependent longterm potentiation in the hippocampus. Exp Physiol 1992, 77:77I-797.

4. Lee HK, Kameyama K, Huganir RL, Bear MF: NMDA induces longterm synaptic depression and dephosphorylation of the GluRI subunit of AMPA receptors in hippocampus. Neuron 1998, $21: 1151-1162$.

5. Salter MW, Kalia LV: Src kinases: a hub for NMDA receptor regulation. Nat Rev Neurosci 2004, 5:317-328.

6. Gingrich JR, Pelkey KA, Fam SR, Huang Y, Petralia RS, Wenthold RJ, Salter MW: Unique domain anchoring of Src to synaptic NMDA receptors via the mitochondrial protein NADH dehydrogenase subunit 2. Proc Natl Acad Sci USA 2004, I 01:6237-6242.

7. MacDonald JF, Jackson MF, Beazely MA: G protein-coupled receptors control NMDARs and metaplasticity in the hippocampus. Biochim Biophys Acta 2007, 1 768:94I-95I.

8. Westbrook GL, Krupp JJ, Vissel B: Cytoskeletal interactions with glutamate receptors at central synapses. Soc Gen Physiol Ser 1997, 52:163-175.

9. Paoletti $P$, Ascher $P$ : Mechanosensitivity of NMDA receptors in cultured mouse central neurons. Neuron 1994, 13:645-655.

10. Lei S, Czerwinska E, Czerwinski W, Walsh MP, MacDonald JF: Regulation of NMDA receptor activity by $F$-actin and myosin light chain kinase. J Neurosci 200I, 2 1:8464-8472.

II. Morishita W, Marie H, Malenka RC: Distinct triggering and expression mechanisms underlie LTD of AMPA and NMDA synaptic responses. Nat Neurosci 2005, 8: 1043-1050.

12. Kotecha SA, Oak JN, Jackson MF, Perez Y, Orser BA, Van Tol HH, MacDonald JF: A D2 class dopamine receptor transactivates a receptor tyrosine kinase to inhibit NMDA receptor transmission. Neuron 2002, 35: IIII-1 I 22.

13. Beazely MA, Tong A, Wei WL, Van Tol H, Sidhu B, MacDonald JF: D2-class dopamine receptor inhibition of NMDA currents in prefrontal cortical neurons is platelet-derived growth factor receptor-dependent. J Neurochem 2006, 98:1657-1663.

14. Lei S, Lu WY, Xiong ZG, Orser BA, Valenzuela CF, MacDonald JF: Platelet-derived growth factor receptor-induced feed-forward inhibition of excitatory transmission between hippocampal pyramidal neurons. J Biol Chem 1999, 274:30617-30623.

15. Valenzuela CF, Xiong Z, MacDonald JF, Weiner JL, Frazier CJ, Dunwiddie TV, Kazlauskas A, Whiting PJ, Harris RA: Platelet-derived growth factor induces a long-term inhibition of N-methyl-Daspartate receptor function. I Biol Chem 1996, 27 I: I6I5I-I6I59.

16. Wong S, Witte ON: The BCR-ABL story: bench to bedside and back. Annu Rev Immunol 2004, 22:247-306.

17. Moresco EM, Koleske AJ: Regulation of neuronal morphogenesis and synaptic function by Abl family kinases. Curr Opin Neurobiol 2003, 1 3:535-544.
18. Moresco EM, Scheetz AJ, Bornmann WG, Koleske AJ, Fitzsimonds RM: Abl family nonreceptor tyrosine kinases modulate shortterm synaptic plasticity. J Neurophysiol 2003, 89:1678-1687.

19. Lanier LM, Gertler FB: From Abl to actin: Abl tyrosine kinase and associated proteins in growth cone motility. Curr Opin Neurobiol 2000, 10:80-87.

20. Moresco EM, Donaldson S, Williamson A, Koleske AJ: Integrinmediated dendrite branch maintenance requires Abelson (Abl) family kinases. J Neurosci 2005, 25:6105-6I।8.

21. Jones SB, Lu HY, Lu Q: Abl tyrosine kinase promotes dendrogenesis by inducing actin cytoskeletal rearrangements in cooperation with Rho family small GTPases in hippocampal neurons. J Neurosci 2004, 24:8510-852I.

22. Katoh H, Aoki J, Ichikawa A, Negishi M: p 160 RhoA-binding kinase ROKalpha induces neurite retraction. J Biol Chem 1998, 273:2489-2492

23. Bito $H$, Furuyashiki $T$, Ishihara $H$, Shibasaki $Y$, Ohashi $K$, Mizuno K, Maekawa M, Ishizaki T, Narumiya S: A critical role for a Rho-associated kinase, p I60ROCK, in determining axon outgrowth in mammalian CNS neurons. Neuron 2000, 26:43I-44I.

24. Da Silva JS, Medina M, Zuliani C, Di Nardo A, Witke W, Dotti CG: RhoA/ROCK regulation of neuritogenesis via profilin llamediated control of actin stability. J Cell Biol 2003, 162:1267-1279.

25. Zandy NL, Pendergast AM: Abl tyrosine kinases modulate cadherin-dependent adhesion upstream and downstream of Rho family GTPases. Cell Cycle 2008, 7:444-448.

26. Mauro MJ, Druker BJ: STI57 I: a gene product-targeted therapy for leukemia. Curr Oncol Rep 200I, 3:223-227.

27. Druker BJ, Tamura S, Buchdunger E, Ohno S, Segal GM, Fanning S, Zimmermann J, Lydon NB: Effects of a selective inhibitor of the Abl tyrosine kinase on the growth of Bcr-Abl positive cells. Nat Med 1996, 2:561-566.

28. Carroll M, Ohno-Jones S, Tamura S, Buchdunger E, Zimmermann J, Lydon NB, Gilliland DG, Druker BJ: CGP $\mathbf{5}$ a tyrosine kinase inhibitor, inhibits the growth of cells expressing BCR-ABL, TEL-ABL, and TEL-PDGFR fusion proteins. Blood 7/48, 90( I 2):4947-4952.

29. Turrigiano G: Homeostatic signaling: the positive side of negative feedback. Curr Opin Neurobiol 2007, 17:318-324.

30. Plattner R, Irvin BJ, Guo S, Blackburn K, Kazlauskas A, Abraham RT, York JD, Pendergast AM: A new link between the c-Abl tyrosine kinase and phosphoinositide signalling through PLCgammal. Nat Cell Biol 2003, 5:309-319.

31. Plattner R, Koleske AJ, Kazlauskas A, Pendergast AM: Bidirectional signaling links the Abelson kinases to the platelet-derived growth factor receptor. Mol Cell Biol 2004, 24:2573-2583.

32. Smart JE, Oppermann H, Czernilofsky AP, Purchio AF, Erikson RL, Bishop JM: Characterization of sites for tyrosine phosphorylation in the transforming protein of Rous sarcoma virus (pp60v-src) and its normal cellular homologue (pp60c-src). Proc Natl Acad Sci USA I98I, 78:60I 3-60I7.

33. Cooper JA, Gould KL, Cartwright CA, Hunter T: Tyr527 is phosphorylated in pp60c-src: implications for regulation. Science 1986, $231:|43|-\mid 434$.

34. Proepper C, Johannsen S, Liebau S, Dahl J, Vaida B, Bockmann J, Kreutz MR, Gundelfinger ED, Boeckers TM: Abelson interacting protein I (Abi-I) is essential for dendrite morphogenesis and synapse formation. Embo J 2007, 26: I397-I409.

35. Stuart JR, Gonzalez FH, Kawai H, Yuan ZM: c-Abl interacts with the WAVE2 signaling complex to induce membrane ruffling and cell spreading. J Biol Chem 2006, 28 I:3 I290-3I 297.

36. Van Etten RA: Cycling, stressed-out and nervous: cellular functions of c-Abl. Trends Cell Biol 1999, 9:179-186.

37. Ishizaki T, Uehata M, Tamechika I, Keel J, Nonomura K, Maekawa M, Narumiya S: Pharmacological properties of Y-27632, a specific inhibitor of rho-associated kinases. Mol Pharmacol 2000, 57:976-983

38. Westphal RS, Soderling SH, Alto NM, Langeberg LK, Scott JD: Scar/ WAVE-I, a Wiskott-Aldrich syndrome protein, assembles an actin-associated multi-kinase scaffold. Embo J 2000, 19:4589-4600.

39. Roskoski R Jr: Src kinase regulation by phosphorylation and dephosphorylation. Biochem Biophys Res Commun 2005, 33 I:I-14.

40. Wang YT, Salter MW: Regulation of NMDA receptors by tyrosine kinases and phosphatases. Nature 1994, 369:233-235. 
4I. Yu XM, Askalan R, Keil GJ 2nd, Salter MW: NMDA channel regulation by channel-associated protein tyrosine kinase Src. Science 1997, 275:674-678.

42. Lu YM, Roder JC, Davidow J, Salter MW: Src activation in the induction of long-term potentiation in CAI hippocampal neurons. Science 1998, 279:1363-1367.

43. Veracini L, Franco M, Boureux A, Simon V, Roche S, Benistant C: Two functionally distinct pools of Src kinases for PDGF receptor signalling. Biochem Soc Trans 2005, 33:13|3-I3|5.

44. Veracini L, Franco M, Boureux A, Simon V, Roche S, Benistant C: Two distinct pools of Src family tyrosine kinases regulate PDGF-induced DNA synthesis and actin dorsal ruffles. J Cell Sci 2006, I I 9:2921-2934.

45. Kim CH, Lisman JE: A role of actin filament in synaptic transmission and long-term potentiation. I Neurosci 1999, 19:43|4-4324.

46. Krucker T, Siggins GR, Halpain S: Dynamic actin filaments are required for stable long-term potentiation (LTP) in area CAl of the hippocampus. Proc Natl Acad Sci USA 2000, 97:6856-686I.

47. Hirose M, Ishizaki T, Watanabe N, Uehata M, Kranenburg O, Moolenaar WH, Matsumura F, Maekawa M, Bito H, Narumiya S: Molecular dissection of the Rho-associated protein kinase ( $\mathrm{F}$ 60ROCK)-regulated neurite remodeling in neuroblastoma NIE-I I5 cells. J Cell Biol 1998, I41:1625-1636.

48. Nakayama AY, Harms MB, Luo L: Small GTPases Rac and Rho in the maintenance of dendritic spines and branches in hippocampal pyramidal neurons. J Neurosci 2000, 20:5329-5338.

49. Wang LY, MacDonald JF: Modulation by magnesium of the affinity of NMDA receptors for glycine in murine hippocampal neurones. J Physiol 1995, 486(Pt I):83-95.

Publish with Biomed Central and every scientist can read your work free of charge

"BioMed Central will be the most significant development for disseminating the results of biomedical research in our lifetime. "

Sir Paul Nurse, Cancer Research UK

Your research papers will be:

- available free of charge to the entire biomedical community

- peer reviewed and published immediately upon acceptance

- cited in PubMed and archived on PubMed Central

- yours - you keep the copyright

Submit your manuscript here:

http://www.biomedcentral.com/info/publishing_adv.asp
BiolMedcentral 